\title{
The Classification of Corruption in Indonesia: A Behavioral Perspective
}

\author{
Rizki Hamdani ${ }^{1}$, Kumalahadi $^{1}$, and Dekar Urumsah $^{1}$ \\ ${ }^{1}$ Accounting Department, Faculty of Economics, Universitas Islam Indonesia, Indonesia
}

\begin{abstract}
This research is aimed to investigate and identify the pattern and classification of corruptors in Indonesia, especially the state officials being imprisoned. This research used the qualitative method. The data were collected through documentations and interviews. The source of the data was chosen by purposive sampling technique. The researcher interviewed deeply 9 suspects of corruption cases being imprisoned. The results of the research show that the classification of corruptors in Indonesia includes all types of corruptions constructed by the Association of Certified Fraud Examiners (ACFE), namely: conflict of interest, bribery, illegal gratuities, and economic extortion. Based on the interview, it is found that the interviewees perform different types of corruptions as follows: there are some suspects perform more than one type of corruptions; there are some suspects perform single corruptions with the same type, and there are some suspects perform single corruptions with the different type. In Indonesia, it is not only the people of executive, legislative, and judiciary who can perform corruptions, but also the people of private sections.
\end{abstract}

\section{Introduction}

Corruption is an act of utilizing a public function to self-benefit that extremely leads to bad impacts to the development of social and economy condition of a country $[1,2,3]$. Some literature show that the practice of corruption affects negatively to the economical development [4], productivity [5], investment [2], entrepreneurship [6], international and domestic trades [7, 8], informal sections [9] based on the transmission of public services [10], and frame a country up from a long poverty [11].

Ironically, the Index of Corruption Perception in Indonesia in the last ten years is not more than 4. This condition is categorized as bad. If it is compared with some countries such as Malaysia and Singapore, Indonesia is left behind in 2014. Malaysia gets 52 and is ranked 50, while Singapore gets 84 and is ranked 7 [12].

The Audit Board of the Republic of Indonesia in Semester Examination Results Summary I (IHPS I) of 2014 reveals 4.900 cases valued Rp 25.74 million billion which harm this country [13]. The Indonesian Corruption Watch (ICW) releases the results of an investigation on semester I, a period of $1^{\text {st }}$ January $-30^{\text {th }}$ June 2014 , that there are 308 corruption cases revealed by the Police, Prosecutor, and The Corruption Eradication

\footnotetext{
*Corresponding author: rizki.hamdani@uii.ac.id
} 
Commission of Indonesia (KPK). They state that the trend of corruptions tends to increase. Meanwhile, on the same semester in 2013, there are 257 cases revealed [14]. The results of the investigation on semester II, a period of $1^{\text {st }}$ July $-27^{\text {th }}$ December 2014, show that there are 629 cases. Meanwhile, in the same semester in 2013 there are 560 cases. It means that there are 69 more cases [15]. If it is summed up, the total numbers of corruption cases during 2014 are 629 cases with 1.328 suspects and country's loss of Rp 5.29 million billion. During 2013, there are 1.271 corruption cases revealed [16]. It can be concluded that compared with 2013, the corruption cases during 2014 increases. The data from the surveys of Indonesian International Transparency show that the members of the House of Representatives from Partai Golkar are 19 people, Partai Demokrasi Indonesia Perjuangan is 17 people, Partai Demokrat is 4 people, Partai Amanat National are 3 people, Partai Persatuan Pembangunan is 3 people, Partai Kebangkitan Bangsa is 1 person, Partai Keadilan Sejahtera is 1 person, and Partai Bintang Reformasi is 1 person [17].

This research is aimed to deeply investigate the classification of corruptors in Indonesia. By viewing the corruptors' sides, it can be revealed a deeper understanding of corruption potentials which can be used as a reference to coping with corruptions [18]. Moreover, [18] shows that if potential suspects are forced, motivated, getting a chance, and having rationales to do a corruption, they are (consciously or not) considering the benefits and costs gotten before deciding to do or not to do the corruption. Viewing and understanding the mechanism in which the potential suspects decide to be involved or not will provide a strong basic for the government and decision makers to construct effective strategies to eradicate corruptions.

\section{Literature Review}

This part provides the literature review on the corruption issues. The review discusses the types of corruptions, the rationales of corruption, the effects of corruption, the role of against-corruption organizations in the world and Indonesia, and the pattern of corruptions in Indonesia.

\subsection{The Types of Corruptions}

The professional organization auditing fraud, Association of Certified Fraud Examiners (ACFE), in the United States describes occupational fraud in the form of fraud tree $[19,20]$. The diagram is shaped like a tree with branches and twigs so that it is named fraud tree. The three main branches of the fraud tree are corruption, asset misappropriation, and fraudulent statements. Moreover, there is also a formula for the types of corruptions which consists of conflict or interest, bribery, illegal gratuities, and economic extortion $[19,20]$.

\subsection{The Pattern of Corruptions in Indonesia}

As written in the Acts Number 31, 1999, the pattern of corruptions happened here is in the context of bureaucracy. In each case of corruptions in Indonesia, the mass media always reveal the name of the individuals doing corruptions and some of the corruptors are proven in a red handed operation by $K P K$. In fact, there is a pattern of corruptions done by the corruptors in all of their deeds. Therefore, the pattern of corruptions in Indonesia is not randomly done and is not incidentally conducted. The pattern is systematically done and is able to be constructed [21]. The corruptors do the action in a system which consists of Principal-Agent-Client-Middlemen (PACM). Figure 1 shows the pattern of corruptions in a bureaucracy taking the state budget. 


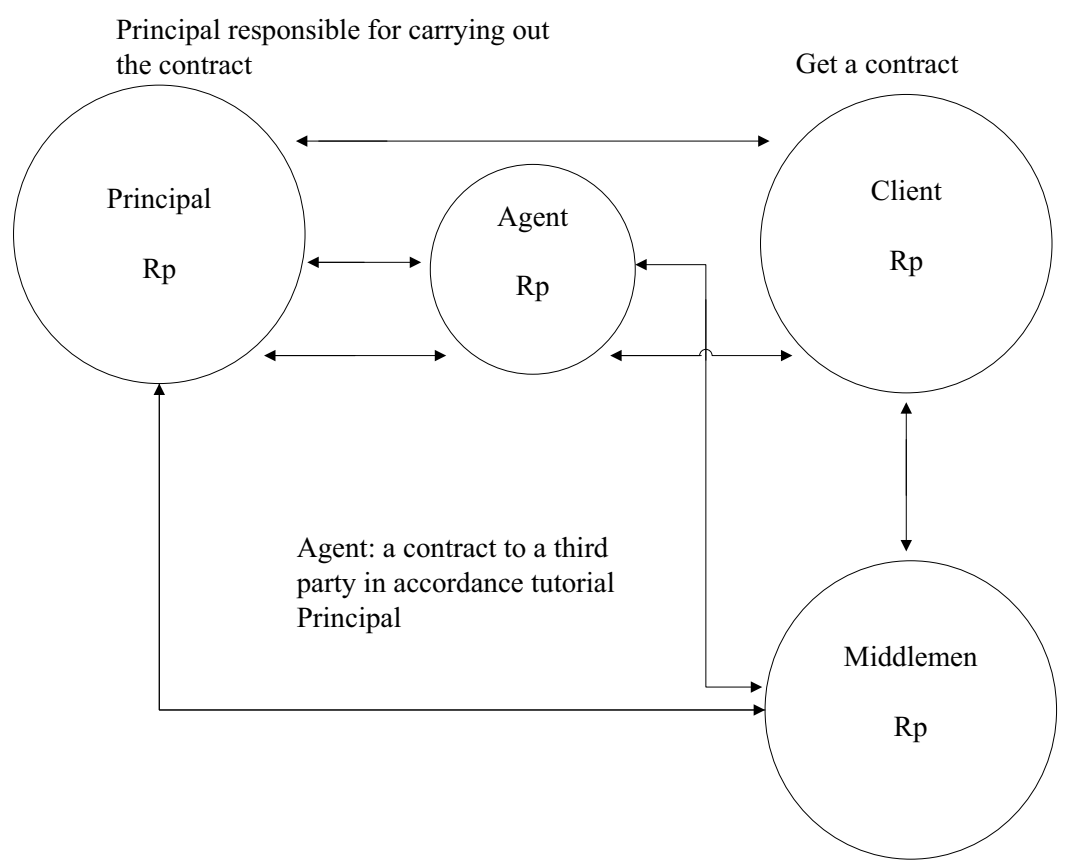

Fig. 1. The Pattern of Corruptions in a Bureaucracy [21]

In Figure 1 above, it is shown that the network of corruption happens systematically and is organized neatly. The pattern shows that corruptions cannot be done by only oneself. In the Principal circle or the government as the ruler or budget, users are responsible for conducting the contract and giving charge to the Agent (division head/division of government procurement) to do the contract to third party - the Client. Before doing so, the Principal has ordered the Agent that the tender must be given to the Client and or the Principal-Agent uses Middlemen's help to link to the Client. In short, the Middlemen act as the connector of the corporate network (Client) and the network inside the government (Principal-Agent).

\section{Research Method}

The source of the data was selected based on the purposive sampling technique. The data were collected through a semi-structured interview with 9 interviewees of suspects in the cases of corruption being prisoned. The research used the qualitative method because the objectives were to investigate the pattern and the classification of corruptors in Indonesia viewed from the corruptors in the prison. [22] explain that qualitative method is used to give a deeper understanding of the issues that involve the perspective of the population and the context in which they live. Specifically, qualitative research is also beneficial to explore new topics or to understand complex problems, to explain human's attitudes and beliefs, and to identify social norms or cultures [22]. Therefore, the qualitative method fits this research because the research dealt with corruptions in the context of accounting which is believed as a new topic and is worth considering. Figure 2 illustrates the procedure of this research. 


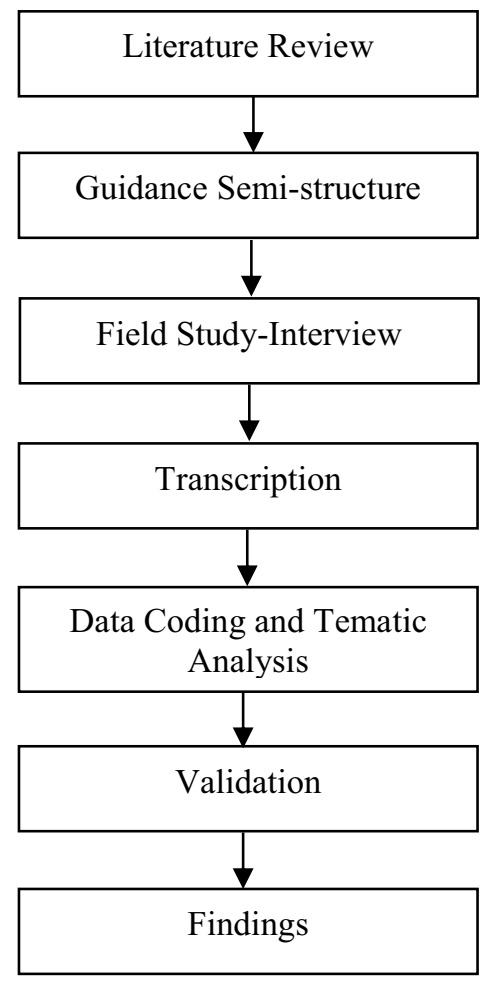

Fig. 2. The Process of Qualitative Research Method

\section{Results and Discussion}

Table 1 shows the background of the respondents based on their affiliation and their position.

Table 1. The Profile of the Interviewees

\begin{tabular}{|l|l|l|l|}
\hline No. & Respondent & Position & Institution \\
\hline 1 & Interviewee A & Legislative & Member of $D P R$ \\
\hline 2 & Interviewee B & Legislative & Head of $D P R D$ \\
\hline 3 & Interviewee C & CEO & Private \\
\hline 4 & Interviewee D & Executive & Regional Government \\
\hline 5 & Interviewee E & Executive & Regional Government \\
\hline 6 & Interviewee F & Judicative & Judiciary \\
\hline 7 & Interviewee G & Executive & Regional Government \\
\hline 8 & Interviewee H & Legislative & DPRD \\
\hline 9 & Interviewee I & CEO & Private \\
\hline
\end{tabular}

Table 1 shows that three people come from the executive position, three people come from 
the legislative position, one person comes from the judiciary, and two people come from the private company.

The results of the interview are classified based the ACFE as shown in Table 2 below.

Table 2. The Classifications of Corruptors in Indonesia

\begin{tabular}{|l|l|l|l|l|}
\hline Code & $\begin{array}{l}\text { Conflict of } \\
\text { Interest }\end{array}$ & Bribery & $\begin{array}{l}\text { Illegal } \\
\text { Gratuities }\end{array}$ & $\begin{array}{l}\text { Economic } \\
\text { Extortion }\end{array}$ \\
\hline A & - & - & $\sqrt{ }$ & - \\
\hline B & $\sqrt{ }$ & - & - & - \\
\hline C & $\sqrt{ }$ & $\sqrt{ }$ & - & - \\
\hline D & V & $\sqrt{ }$ & - & - \\
\hline E & - & $\sqrt{ }$ & - & - \\
\hline F & - & - & $\sqrt{ }$ & $\sqrt{ }$ \\
\hline G & V & - & - & - \\
\hline H & V & - & - & - \\
\hline I & V & - & - & - \\
\hline
\end{tabular}

Based on Table 2 above, corruptors classified in the conflict of interest are six people, bribery is three people, illegal gratuities are two people, and economic extortion is one person. From the nine suspects, it is identified that $\mathrm{C}, \mathrm{D}$, and $\mathrm{F}$ perform two types of corruption: $\mathrm{C}$ and $\mathrm{D}$ perform conflict of interest and bribery, while $\mathrm{F}$ performs illegal gratuities and economic extortion.

The interviewee $\mathrm{C}$ is identified performing conflict of interest and bribery based on C's statement as follows:

"I confess that I gave the regent and some persons in the ministry money. They asked the money and promised me the tender. Corruptions are very organized in Indonesia. If we want to get the tender, we need to use money in the governmental bureaucracy. In the ministry, in the province, and in the region, there are many corruption practices by asking for money to the company given the tender by the government. If we do not do that, we will not get the tender from the government."

From the interview with interviewee $\mathrm{D}$, the executives give a guarantee for their workers who have been accused to move them from prison into the city custody by employing a fee lawyer to accompany the accused ones so that the workers can be free. By doing so, the executives will not be involved in the court. Interviewee D tends to confess that he has helped his workers in the judiciary process. He explains his involvement in the corruption practice that he has done conflict interest and bribery:

"In the report of the Audit Board of Indonesia about the financial report of the Regional Government in which I governed in 2010, the country's loss is Rp 40 million billion in the use of social finance during 2009-2010 which should be accountable. However, I had ordered the inspectorate at that time to send the budget user - the region secretary and the head of financial and asset management to report it. At that case, I was involved in the social support. My staff once told me that he was stressful because the judges always asked for money. I helped him give a guarantee for the accused to move him from prison into city custody. I employ fee lawyer to assist the accused ones and was helped by the city government as my moral responsibility as a chief."

Different from interviewee $\mathrm{C}$ and $\mathrm{D}$, interviewee $\mathrm{F}$ performs two types of corruptions. Interviewee $\mathrm{F}$ performs the illegal gratuities and economic extortion even though he does not admit it. However, the judge judges him provenly guilty and assures him receiving 
money from the entrepreneur and doing extortion to the former chief in the central government. The following is the explanation from interviewee $\mathrm{F}$.

"Both $K P K$ and the Judiciary have already investigated the case I am handling, so there is no any factor violating the law as they accuse. It is clearly recommended that the team does not find any enough proof to move this case into the investigation level. Moreover, there is a clear mistake in presenting the proof in the court. It relates to the witness' explanation which comes from only one person without other witnesses or proofs. Ironically, it is used for the proof to accuse me."

The differences of corruptions performed by $\mathrm{C}, \mathrm{D}$, and $\mathrm{F}$ are: (1) $\mathrm{C}$ is a CEO who has the conflict of interest to a person in the government to win the tender, so $\mathrm{D}$ must bribe the person in the government who asks for money; (2) D is an executive in the regional government who has the conflict of interest to his workers and the judges so that he is not involved in the case, so D bribes to the judges, and; (3) F is a person in judiciary who does the economic extortion to the chief of central government so that the case being investigated will not be processed. The money gotten is used for illegal gratuities in the form of business deal.

Three of nine suspects have a similar pattern of corruptions which is a conflict of interest. The suspects are interviewees G, H, and I.

In the court, the judges judge interviewee $G$ as personally and systematically enrich himself, others, or a corporation, so it causes a billion losses for the country [23]. Interviewee $\mathrm{G}$ is proven to violate the law with the fund of billion rupiahs from the regional government to his personal bank account. The fact is proven by the invoice which cannot be denied by him in the court. He is proven using the money for his personal interest such as buying a house. However, in the interview he says that:

"As a chief of the regional government, I only want to fasten the regional development. I work for my people in my region. I never order my staff to perform corruptions. The judiciary is not doing a fair investigation in this case, so there are many bizarre things and unfairness. The regional secretary and commitment makers should have been the one who is responsible for this, but they have never been investigated. I am a passive person in this project. It can endanger the judiciary and the corruptions will never end."

The corruption performed by interviewee $\mathrm{H}$ is about fiction insurance of the members of Regional People's Representative Assembly (DPRD). The case makes the regional government lost billions of rupiahs. The case is started from the insurance program between $D P R D$ and insurance company. The program offers one year premise with the total amount of it of Rp 2 billion. However, the implementation of the cooperation is never conducted. Interviewee $\mathrm{H}$ is judged guilty. He explains that:

"In the previous meetings discussing budgets, actually, there is no budget for the life insurance. The budget for the members appears when DPRD and other members meet the city major. At that time, the city major promised the members grate after retired, but the form was not clearly thought. After some meetings, it was agreed that it was in the form of life insurance. The members of the representatives never knew and were never involved in the cancellation because there was no formal cancellation from the DPRD secretary. The cancellation was done by the order of the chief of DPRD."

Interviewee $\mathrm{I}$ is a CEO in one of the private companies in Indonesia. He is judged as making the country lose because of violating frequency streamer. As the result, the company gets significant benefits. According to the report of the Financial and Development Supervisory Agency (BPKP), the company makes the country lose tip to Rp 1 million billion. However, in the interview, he explains that he does not perform the corruption as accused by the Judiciary. The following is interviewee I' explanation:

".... from where the corruption is. The cooperation between the companies is based on the law because it suits the Acts and there are operational regulations. The cooperation 
agreement between the central company and the company I lead is a corporation and is not a performance of the director."

The differences between G, H, and I are: (1) G is a regional chief who performs conflict of interest with his staff members by violating regional budgets in the infrastructure project, (2) $\mathrm{H}$ is a chief of DPRD who performs conflict of interest with the members of DPRD by creating fiction project of insurance premise, and (3) I is a CEO of a private company who cooperate with the government in making frequency streamer, but unwillingly it causes the country loss. The similarity between G, H, and I is that they perform conflict of interest systematically and involve many people.

There are three suspects who perform a single corruption, but slightly different. A performs illegal gratuities, B performs conflict of interest, and E performs bribery.

Interviewee $\mathrm{A}$ is a member of House of Representatives (DPR) who is proven guilty of performing corruption and illegal gratuities many times. The Judges judge him guilty because he performs corruption as mentioned in Article 3 of the Acts Number 8, 2010 about the prevention and the eradication of money laundry. However, interviewee A convinces that he is not guilty and does not perform corruption as judged by the Judges. The following is interviewee A' statement:

".... I am accused of receiving a gratification by the judiciary in the court because of one suspect's statement. They should have proven that I really receive it, but they cannot. I am asked to prove myself that I am not guilty. In my case, the prosecutor cannot prove in the court, but judges me guilty. There is an influence from the media in the decision of corruption cases in Indonesia nowadays. Thus, the judges' judgment is really influenced by the news in the public and do not take a look at the the fact and proof in the court. The judgment is unfair because it is not based on the facts in the court."

Interviewee $\mathrm{B}$ is a suspect of the corruption case of the official tour in $D P R D$, instrument of representatives, and the discussion of regional regulation for hundreds of billion rupiahs when he governs as the chief of DPRD. He states that there is an agreement in performing the corruption in $D P R D$. For example, he allows the members not to join the official tour, but still get the fund. In another case, there are some members who receive money from the official tour warrant, but they do not do the managed tour. In every official tour, they always use the travel agent recommended by other members of DPRD. The following is interviewee B' explanation:

"I admit that there are some members who do not join the official tour but still receive the money. Because this is a systemic mistake, the chief and the members should be suspected. The case of the official tour is known by all chiefs and members, so it is impossible if others do not know. The chiefs are collegial and collective, so it cannot be blamed on one person only. It becomes our responsibility, all chiefs."

Interviewee $\mathrm{E}$ is a suspect in the corruption case of social fund in the city government and bribery to persons of judges handling the case. He explains the bribery he performs as follows:

"My case is the social fund. It is purposed for the society in their programs. It is for a good purpose, basically. It helps them. Every region provides the fund. The chief orders us to give money to the chief of the Judges. The city major orders me to handle the coordination of the fund collection with the regional chiefs. We only conduct the order. There is a record of my talk with the city major and I open all of the cases in the court. I help $K P K$ in this case because I become the justice collaborator."

The differences between A, B, and E are: (1) A performs illegal gratuities in the project of infrastructure development, (2) B performs conflict of interest in the form of violating the fund of official tour and instruments of representative members, and (3) E performs 
bribery for himself and not for his staff in the court. The similarity between A, B, and E is that they only perform one type of corruptions.

The results of the research show that the classification of corruptors in Indonesia includes all types of corruptions constructed by ACFE [19, 20], namely conflict of interest, bribery, illegal gratuities, and economic extortion. Based on the interview, it is found that 9 suspects perform different types of corruptions. There are some suspects perform more than one types of corruptions, single corruption in the same type, and single corruption in the different type.

The researcher also finds that in Indonesia, it is not only the people of executive, legislative, and judiciary who can perform corruptions, but also the people of private sections. All of them cause the country loss as the pattern investigated by Indriati [21].

\section{Conclusions and Suggestions}

All the types of corruptions constructed by the Association of Certified Fraud Examiners (ACFE) namely conflict of interest, bribery, illegal gratuities, and economic extortion are found in the corruption cases in Indonesia. The nine interviewees can be categorized into there types of classification as follows: (1) 3 people perform more than one types of corruption; (2) three people perform single corruption with the same type, and (3) 3 people perform single corruption with a different type.

Based on the pattern investigated by Indriati [20], in Indonesia, it is not only the people of executive, legislative, and judiciary who can perform corruptions, but also the people of private sections who can make the country loss.

The researcher suggest that the central and regional government in Indonesia design or strengthen the fraud control plan on the sections being corrupted, especially on the sections used as the field to corrupt as found in this research, namely license, budget violation, and goods or services procurement; fix and strengthen the system of corruption prevention in every government institutions such as executive, legislative, and judiciary; support all regional government in Indonesia to create e-budgeting and e-procurement in constructing regional budget and procurement of goods and services; and strengthen and employ Government Internal Supervisory Apparatus (APIP) such as regional inspectorate in provinces and cities and $B P K P$.

This research has some limitations as follows: (1) this research is only focused on the interviewees of suspected in the corruption prisons and (2) the data related to the potential of the country' loss, judges' judgment, and the period of being suspected are gained from the internet.

\section{References}

1. P. Bardhan. Corruption and Development: A Review of Issues. J. Econ. Lit. 35, 13201346 (1997).

2. K. M. Murphy, A. Shleifer, R. W. Vishny. Why is rent-seeking so costly to growth? Am. Econ. Rev. Pap. Proc. 83, 409-414 (1993).

3. A. Shleifer, R. W. Vishnyi. Corruption. Q. J. Econ. 108, 599-617 (1993).

4. P. Mauro. Corruption and Growth. Q. J. Econ. 110, 681-712 (1995).

5. A. Dreher, T. Herzfeld. The Economic costs of corruption: A Survey and new evidence. no. June 2005 (2005).

6. A. Dreher, M. Gassebner. Greasing the wheels? The impact of regulations and corruption on firm entry. Public Choice 155, 413-432 (2011).

7. C. Bjørnskov. Can bribes buy protection against international competition? Rev. 
World Econ. 148, 751-775 (2012).

8. A. O. Krueger. The Political economy of the rent-seeking society. Am. Econ. Rev. 64, 291-303 (1974).

9. A. Dreher, F. Schneider. Corruption and the shadow economy: An empirical analysis. Public Choice 144, 215-238 (2010).

10. Transparency International. Corruption Perception Index for 2007. Transparency International, Berlin ( 2007).

11. T. S. Aidt. Corruption, institutions, and economic development. Oxford Rev. Econ. Policy 25, 271-291 (2009).

12. Transparency International. Corruption Perceptions Index. Transparency International (2015). Available at: www.transparency.org/cpi. (Accessed: 16th April 2015)

13. The Audit Board of the Republic of Indonesia. Examination results in summary 1st half of 2014. BPK RI, Jakarta (2014).

14. Kompas. ICW: Corruption cases increase in 2014 (2014). Available at: http://nasional.kompas.com/read/2014/08/17/16011471/ICW.Kasus.Korupsi.di.2014.

Meningkat. (Accessed: 21st April 2015)

15. Media Indonesia. The dominance of local government corruption in 2014 (2015). Available at: http://www.mediaindonesia.com/mipagi/read/8452/Pemda-DominasiKorupsi-di-2014/2015/02/18. (Accessed: 21st April 2015)

16. detikNews. Meet the chairman of the council, ICW report surging corruption (2015). Available at: http://news.detik.com/read/2015/03/10/141209/2854525/10/temui-ketuadpd-icw-laporkan-melonjaknya-kasus-korupsi. (Accessed: 21st April 2015)

17. Merdeka.com. This is a list of members of the House of Representatives last 10 years dragged corruption. (2014). Available at: http://www.merdeka.com/politik/ini-daftaranggota-dpr-terseret-korupsi-10-tahun-terakhir.html. (Accessed: 23rd April 2015)

18. H. Y. Prabowo. To be corrupt or not to be corrupt understanding the behavioral side of corruption in Indonesia. J. Money Laund. Control 17, 306-326 (2014).

19. ACFE. 2008 Report to the nation on occupational fraud \& abuse. The Association of Certified Fraud Examiners, Austin, USA (2008).

20. ACFE. Report to the nations on occupational fraud \& abuse: 2016 Global fraud study. The Association of Certified Fraud Examiners, Austin, USA (2016).

21. E. Indriati. Patterns and roots of corruption: Destroying public vicious cycle of Sin. Jakarta: PT Gramedia Pustaka Utama (2014).

22. M. Hennink, I. Hutter, A. Bailey. Qualitative research methods. London: SAGE Publications (2011).

23. Tempo. Regent tegal sentenced to 5.5 years in prison (2011). Available: http://nasional.tempo.co/read/news/2011/11/24/063368297/bupati-tegal-divonis-5-5tahun-penjara. (Accessed: 15th May 2015). 